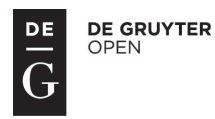

\title{
Procedural SAFEguards Under the European Convention on Human Rights in Public (Administrative) LAW MATTERS
}

\author{
Tina Sever ${ }^{1}$
}

\begin{abstract}
The effectiveness of procedure is important for parties (e.g. citizens or business entities) to be able to exercise their rights in due time and is a key foundation of the rule of law. A State with an effective legal system provides a business-friendly environment, which is appealing for investments. The State decides on permits, licenses, taxes, etc. by applying administrative procedure. The aim of the paper is to identify and analyse such matters under public (administrative) law at the national level, which - due to their influence on private rights or obligations - fall under the civil or criminal limb of Article 6 of the ECHR and its requirements, as well as the requirements of Article 13. By means of a case study and descriptive-analytical and normative methods, the paper identifies comparatively selected cases and analyses the ECtHR test regarding reasonable time, focusing on overall procedure duration and the awarded compensations. The findings show that the ECtHR does not define reasonable time in abstracto. Therefore, the established violations among the states range from two-year procedures to nine years and more, depending on the circumstances of each individual case. Similarly, there are also variations in terms of compensation awarded.
\end{abstract}

\section{Keywords}

Administrative Matters, ECtHR Case Law, Legal Remedy, Just Satisfaction, Reasonable Time, Procedure Effectiveness

\section{Introduction}

The European Convention on Human Rights (ECHR) is a regional document setting minimal standards for the protection of human rights and freedoms in Europe. The European Court of Human Rights (ECtHR) acts on the basis thereof as a supranational institution in charge of the ECHR interpretation, its uniform application, and respect in all 47 Council

\footnotetext{
${ }^{1}$ University of Ljubljana, Faculty of Administration, Gosarjeva ulica 5, 1000 Ljubljana, Slovenia. E-mail:
} tina.sever@fu.uni-lj.si. 
of Europe member states. As defined by Article 1 of the ECHR, all contracting parties have the positive obligation to secure to everyone within their jurisdiction the rights and freedoms established by the ECHR. The States choose by themselves the remedies and the manners of exercising the ECHR rights. The ECtHR cannot abrogate national decisions it can only establish a violation of the ECHR and award compensation. However, in the event of repetitive complaints addressing the same question or problem, thus pointing to structural or systemic deficiencies in national law or practice, the ECtHR can issue pilot judgments, which can define in an abstract way a solution to the problem. Pending the issuing of a pilot judgment, all similar applications are adjourned.

The obligation to respect the ECHR requirements also applies for the Executive, which uses administrative procedure as a basic business process. For citizens and legal entities (e.g. business entities), administrative procedure is one of the most common procedures they will be involved in, since through such procedure the State decides on their rights and obligations (e.g. registering of a private entrepreneur, obtaining a building permit, revocation of a stockbroker's trading licence, craft licence, tax assessment, etc.). These rights are positive rights, requiring a certain activity by the parties themselves in order to acquire them (e.g. to submit a building permit application to the competent public authority). ${ }^{2}$

Typical of administrative matters is the supremacy of public interest over the parties' private interests, putting citizens and business entities in a subordinate and weaker position. In accordance with the principles of democracy and separation of powers, administrative decisions need to be subject to judicial review. Although the right to have access to the court is a fundamental human right, procedures involving several instances should not result in the prolongation of the overall procedure duration, but should be performed and organised so as to ensure effective procedural safeguards. Namely, the aim of the State is to have a functioning legal system providing a stable legal environment. However, when procedures are not performed within a reasonable time, the latter can result in the State's liability for damages. Moreover, conducting procedures within a reasonable time with the use of effective legal remedies is one of the preconditions to form a friendly business environment, appealing for domestic and foreign investments. Otherwise, delays can lead to a multi-layered pecuniary loss for the State in terms of costs of the overall procedures duration (time and costs to keep the entire Executive and Judiciary going), payment for damages, if requested by the affected party, and, finally, the missed opportunity of further investments.

Since justice delayed can lead to justice denied, it is important that procedures are conducted within a reasonable time at all instances, which is also one of the fundamental principles of good administration and good governance. ${ }^{3}$ Thus, limiting the decision-making process to reasonable time frames is one of the most important commitments for both the administrative authorities and the administrative courts. Such is provided by constitutional

\footnotetext{
${ }^{2}$ Cf. Sever, Rakar, Kovač (2014).

${ }^{3}$ See Sever, Rakar, Kovač (2014)
} 
and conventional standards as well as by European Union law ${ }^{4}$ and national legislations. ${ }^{5}$ Each country chooses by itself the means and the manners of the implementation of rights, which can even lead to higher standards than those prescribed by the ECHR. In fact, the latter is considered a minimal standard, providing only subsidiary protection. ${ }^{6}$

The aim of the paper is to identify and analyse such matters under public (administrative) law at the national level, which - due to their influence on private rights and obligations fall under the civil or criminal limb of Article 6 of the ECHR and its requirements, i.e. the right of access to a court and the right to a fair trial within reasonable time. In case of their infringement, an effective national legal remedy should be provided as defined by Article 13 of the ECHR. In this context, the paper deals with the main research question, i.e. the relevance of the ECHR requirements as deriving from Articles 6 and 13 of the ECHR for public (administrative) law matters and the consequences when national authorities fail to fulfil them.

Thus, administrative matters are not purely a national matter. It is important for the parties to be informed of the State's obligation to ensure effective legal procedures at the national level and - in case of infringement of their rights - of the possibility to bring action against the State before the ECtHR. Hence, the paper first analyses the relevant ECtHR case law and its interpretation of Articles 6 and 13 of the ECHR as regards the scope of application and assurance of fundamental procedural guarantees in public (administrative) law matters. In the second part, special focus is given to decision-making within a reasonable time in public (administrative) law matters. The paper analyses the ECtHR test regarding reasonable time and gives an overview of selected cases, focusing on the overall duration of procedure and on awarded compensations. In addition to the case study, descriptiveanalytical and normative methods are used. The main observations of the research are synthesised in the conclusions.

\section{Guarantees deriving from Articles $6 \S 1$ and 13 of the ECHR}

The guarantees deriving from Article $6 \S 1$ of the ECHR are the requirements to be fulfilled in each contracting State, representing the fundamental pillar of democracy. Hence, in the determination of his or her civil rights and obligations or of any criminal charge against him or her, everyone is entitled to a fair and public hearing within a reasonable time by an independent and impartial tribunal established by law.

Since the ECtHR is in charge of the ECHR interpretation (Article 32), it has introduced various principles in this respect. Firstly, the independent nature of the ECHR concepts in relation to national systems; secondly, "development interpretation" (i.e. the ECHR guarantees are in accordance with the actual social needs), ${ }^{8}$ and thirdly, the contracting

\footnotetext{
${ }^{4}$ See Article 41 and Article 47 of the Charter of Fundamental Rights of the EU (2010/C 83/02). See also Article 17 of draft Regulation of the European Parliament and of the Council on an open, efficient and independent European administration (2016).

${ }^{5}$ Sever, Đanić, Kovač (2014).

${ }^{6}$ Articles 13 and 35 of the ECHR; Sürmeli v. Germany (2006, par. 97).

${ }^{7}$ Cf. Van Diyk et al. (2006): "evolutive interpretation".

${ }^{8}$ ECHR as a living instrument; interpreted in the light of present-day conditions (Tyrer v. The United Kingdom
} 
parties have room for manoeuvre as regards the implementation of rights (the principle of subsidiarity). ${ }^{9}$ The above principles are also applicable when interpreting Article $6 \S 1$ of the ECHR. Considering that the ECHR is a living instrument, the ECtHR applies a wide interpretation of the terms "civil rights" and "criminal charges" and understands them as autonomous concepts, not dependent on the national legal systems. ${ }^{10}$

In accordance with the substantive approach, the ECtHR includes under the civil limb all procedures which are decisive for private rights and obligations, even if a dispute is between an individual and a public authority ${ }^{11}$ and regardless of national law, the parties' status, and the nature of the authorities. ${ }^{12}$ Civil rights and obligations must be the object or one of the objects of the dispute and the result of the proceedings must be directly decisive for such right or obligation. ${ }^{13}$ The dispute must be genuine and of a serious nature, giving it a substantive rather than a formal or technical meaning. ${ }^{14}$ Finally, the main idea of the ECHR is the procedural protection of nationally recognised rights, although interpretation is not bound by national legal classification (see Table 1).

A similar, substantive approach was taken when interpreting the term "criminal limb". This concept covers matters defined as criminal under national law. Otherwise, the ECtHR asserts them based on the criteria developed in the Engel v. Netherlands case (1976). Namely, the ECtHR verifies whether national provisions are part of criminal law or of disciplinary proceedings or both, and examines the nature of an act or prohibition and the severity of the penalty. Furthermore, the ECtHR examines the national law of other contracting countries and verifies whether a rule is valid for only a certain group of people (e.g. prisoners, army, etc.) or for the entire population (see Table 1). However, disciplinary proceedings - such as military disciplinary proceedings with sanctions of only five days in prison; disciplinary proceedings against an attorney in the form of a warning; fine for a teacher attending a strike, etc. - are not included under criminal limb. ${ }^{15}$ Based on the above, one can conclude that in the contracting States, the ECtHR also has the power to review the procedures and the decisions of the Executive.

As mentioned in Chapter I, in accordance with the principle of the separation of powers, the actions of the Executive can be subject to judicial review. Sometimes, however, before bringing action before the court, the parties need to exhaust the appeal as a regular legal remedy in administrative procedure (e.g. Slovenia, Croatia, ${ }^{16}$ Netherlands, etc.). Namely, the Executive employs public servants who possess specific professional knowledge and the relevant skills to decide on the matters. Nevertheless, judicial proceedings must be organised in accordance with the ECHR. This means that every party has a right to a fair and public hearing within a reasonable time by an independent and impartial tribunal

(1978, par. 31)).

${ }^{9}$ Macdonald, Matscher and Petzold (1993).

${ }^{10}$ More on civil concept also in Galič (2004).

${ }^{11}$ Sporrong and Lönnroth v. Sweden (1982).

${ }^{12}$ König v. Germany (1978); Sever, Đanić, Kovač (2014).

${ }^{13}$ See Le Compte, Van Leuven and De Meyer v. Belgium (1981).

${ }^{14}$ Benthem v. Netherlands (1985).

${ }^{15}$ Grotrian (1996); Sever (2014).

${ }^{16}$ See Sever, Đanić, Kovač (2016). 
established by law, with the power to establish the facts of the case and issue decisions (see Article $6 \S 1$ of the ECHR and Table 1). When an appeal is a precondition for access to the court, the relevant period in terms of a reasonable time already starts when submitting the appeal to the second instance ${ }^{17}$ (see Table 1). As for the end-point, the ECtHR takes into account the issuance or service of a final decision or, when necessary, also the execution of a decision ${ }^{18}$ (see Table 1). A detailed explanation of the duration of procedures follows in Chapter III.

With a growing number of contracting States ${ }^{19}$ and, consequently, a growing population protected under the ECHR and possibly submitting a complaint to the ECtHR due to human rights violations, the ECtHR found itself with an overload of cases. However, the ECtHR has to set an example as regards respecting human rights, including the right to conduct procedures and issue decisions and judgments within a reasonable time. Moreover, this right is one of the most commonly alleged violations among the contracting States. Therefore, the ECtHR changed its position on Article 13 of the ECHR in the Kudla case (2000) and required that the States already ensured effective legal remedies in case of time limit infringement at the national level, which needed to be exhausted before proceeding further to the ECtHR. ${ }^{20}$

The remedy can be either preventive, meaning that it accelerates the procedure and prevents delays, or serve as compensation for the delays that already occurred. ${ }^{21}$ The regulation that is most effective and mainly recommended by the ECtHR when facing backlogs involves both acceleration and compensation remedies (see Table 1). Compensation is not necessarily financial, but can also be in the form of suspension of prosecution, mitigation of a sentence, exemption from paying legal costs, exemption from or postponing of penalty execution, fine reduction, ${ }^{22}$ non-deprivation of civil and political rights, etc. ${ }^{23}$ However, quashing a ruling on procedural grounds does not suffice as an effective remedy, neither does a favourable outcome. On the other hand, when deciding on administrative matters, the preventive measure of "silentio positivo" can be used. ${ }^{24}$

In accordance with Article 35 of the ECHR, the parties need to exhaust the relevant legal remedies at the national level before proceeding further to the ECtHR. However, when there are systemic violations at the national level and it is clear that the available remedies do not provide any chances for the complainant's success, a direct complaint to the ECtHR without previous exhaustion of national legal remedies is possible.

\footnotetext{
${ }^{17}$ Kiurkchian v. Bulgaria (2005, par. 51 \& 52). See also Božić v. Croatia (2006, par. 26).

${ }^{18}$ Hornsby v. Greece (1997).

${ }^{19}$ Until now, 47 contracting States.

${ }^{20}$ Kudła v. Poland (2000, par. 157). See also Table 1. Cf. Sever (2016).

${ }^{21}$ See Kudła (2000, par. 158).

${ }^{22}$ Mitterbauer v. Austria (2009).

${ }^{23}$ Report on the Effectiveness of National Remedies in Respect of Excessive Length of Proceedings (2006; for case law, see footnotes 181-185).

${ }^{24}$ Report on the Effectiveness of National Remedies in Respect of Excessive Length of Proceedings (2006).
} 

on Human Rights in Public (Administrative) Law Matters

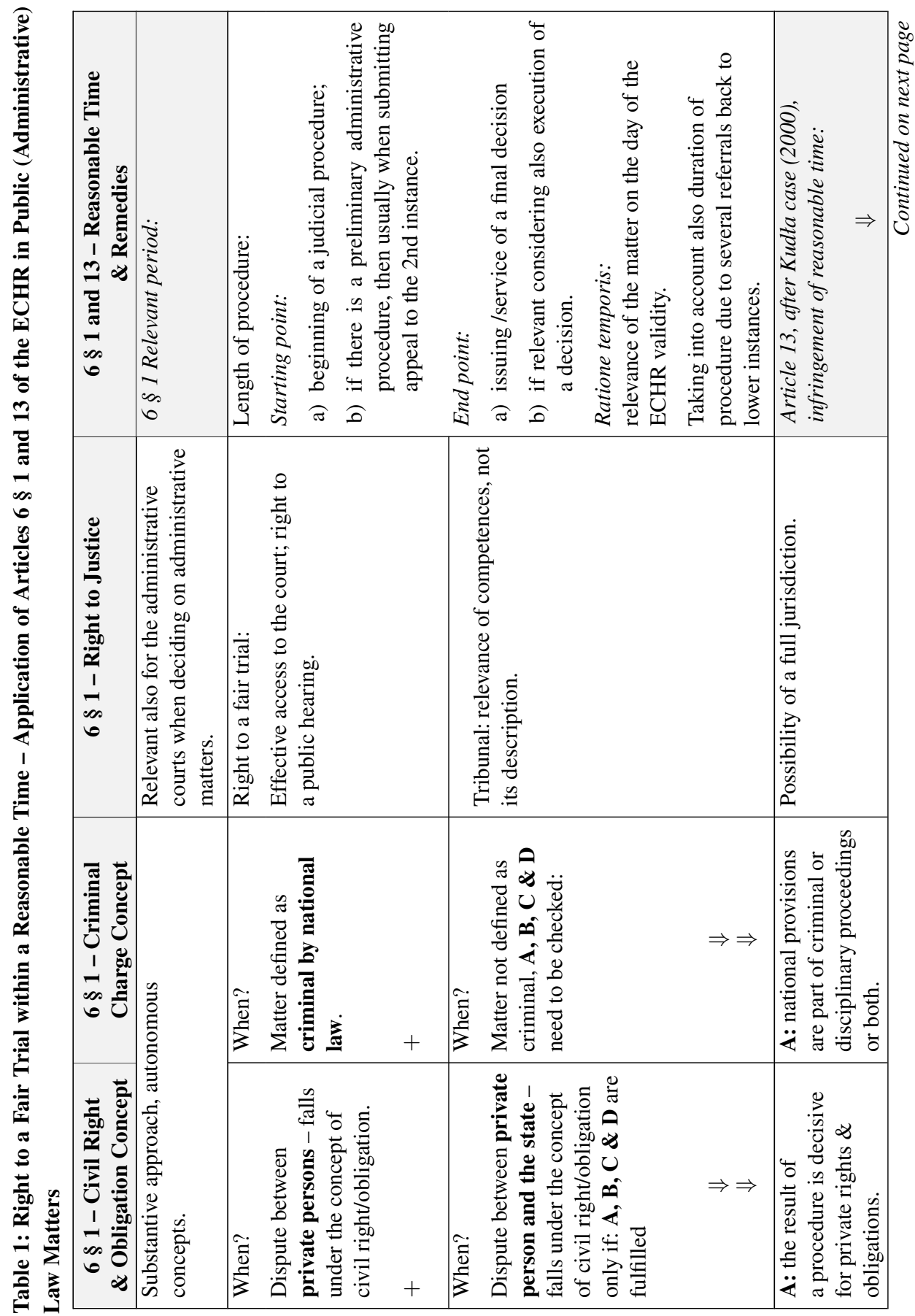




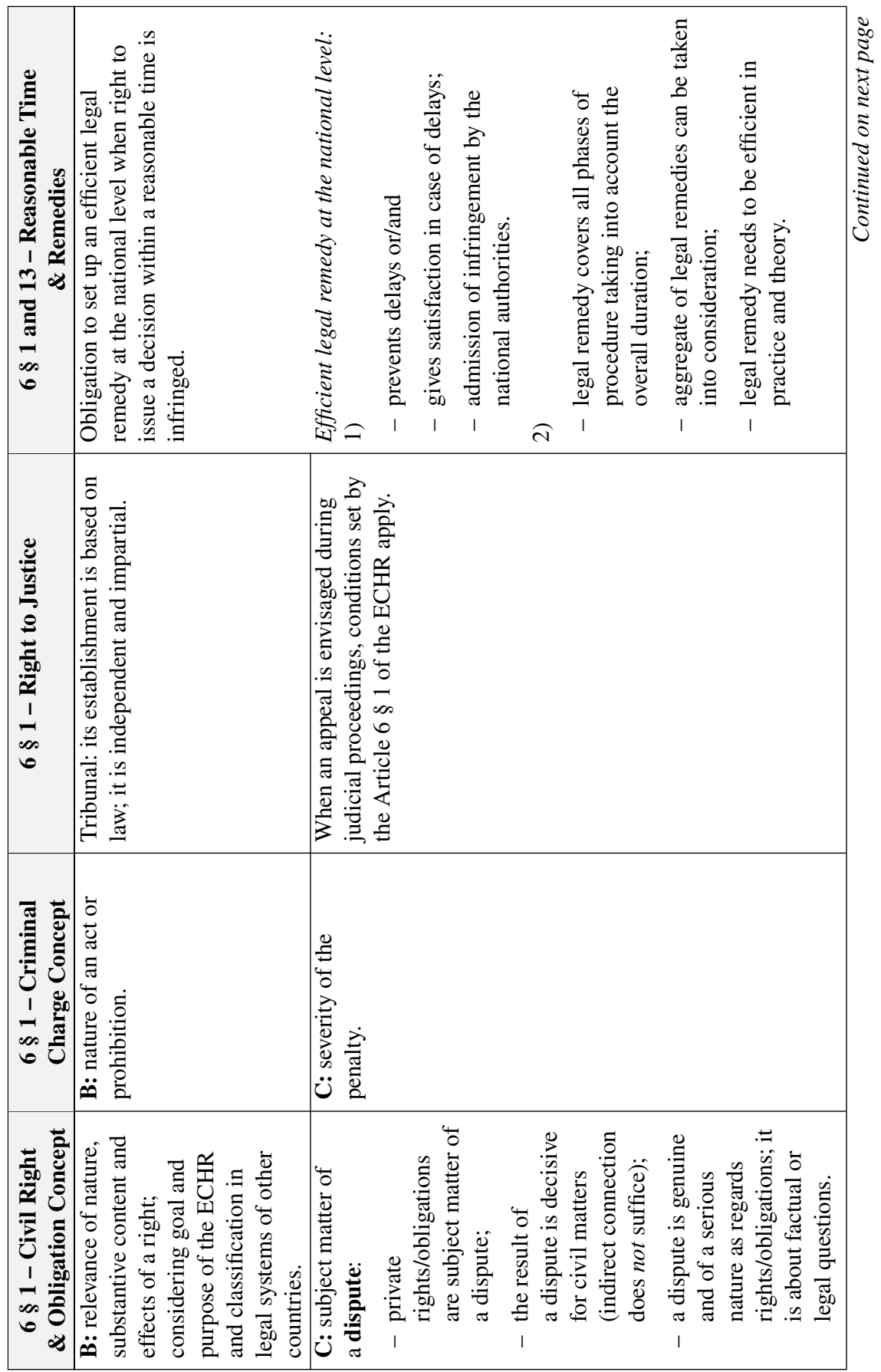




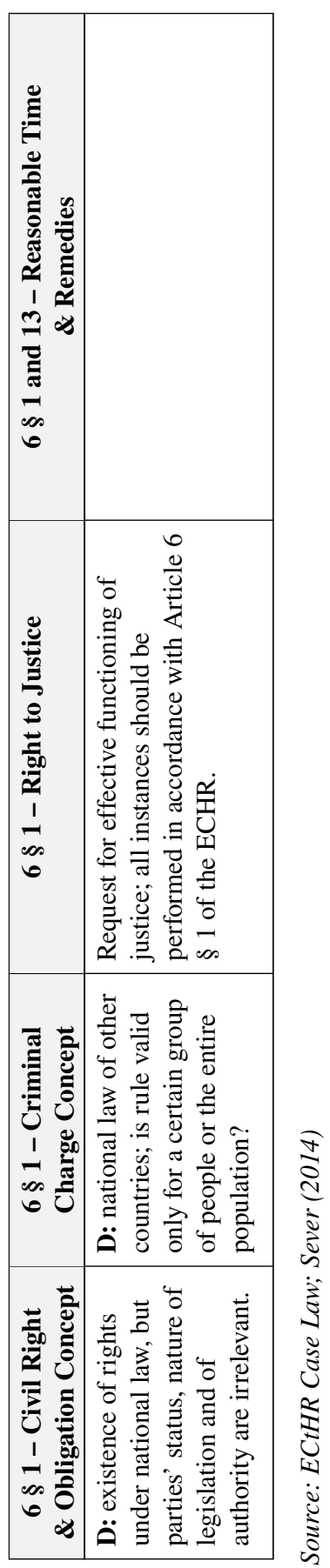


When the ECtHR finds an ECHR infringement, it decides at its own discretion on the compensation and the payment of costs. In some cases, other individual measures may be imposed to restore a previous situation (e.g. reopening of the case, suspension of prosecution, etc.) ${ }^{25}$ or certain general measures to improve the national system (e.g. change of legislation, administrative reforms, case law changes, etc.). ${ }^{26}$ Despite the inter partes nature of the ECtHR judgments, they actually also have an erga omnes effect. ${ }^{27}$ Namely, the sooner the contracting parties change their system in accordance with the requirements deriving from the broad ECtHR interpretation, the less possibility there is for their conviction before the ECtHR. This creates a legally safe environment, which is a precondition for business investments.

\section{Inclusion and Exclusion of Public (Administrative) Law Matters under Article 6 \$ 1 of the ECHR}

When a certain right or obligation is already classified under national law as private law, or having predominantly a private law nature, it falls under Article $6 \S 1$ of the ECHR. However, when a right or obligation is classified as a public (administrative) law matter, its nature in respect of Article $6 \S 1$ of the ECHR has yet to be established (see Chapter II, Table 1). Based on the content and effect of such right or obligation, the ECtHR will establish whether public or private law characteristics prevail. Namely, the ECtHR will verify its content and effect in the national legal system of the respective country as well as its classification in other countries' legal systems, considering the goal and purpose of the ECHR. ${ }^{28}$ Therefore, there is no definition of a civil right or obligation in abstracto. The content still needs to be established in each individual case, based also on the fulfilment of the respective conditions, as explained in the beginning of Chapter II.

According to the broad interpretation of civil and criminal matters as defined by Article $6 \S 1$ of the ECHR, there are several administrative and other public law matters that the ECtHR included in its case law when interpreting the stated article. Under the concept of "civil rights", which are defined as public (administrative) law matters under national law of the contracting parties, it included in particular the granting of licenses, building permits, permits to perform a certain activity (e.g. authorisation to run a pharmacy); expropriation; social security rights, etc. Under the term "criminal charge" it included tax surcharges; tax penalties; disciplinary measures; customs law; misdemeanours, etc. (for a detailed overview on the ECtHR interpretation and inclusion under the civil and criminal limb, see Table 2). ${ }^{29}$ The subject of some of these procedures are both individuals and business entities.

\footnotetext{
${ }^{25}$ See Miller (2011).

${ }^{26}$ See White and Ovey (2010).

${ }^{27}$ Zupančič (2004).

${ }^{28}$ Grotrian (1996). See also Table 1.

${ }^{29}$ Cf. Sever (2016).
} 
Table 2: ECtHR Interpretation of Article $6 \S 1$ of the ECHR - Inclusion of Possible Public (Administrative) Law Matters under Civil and Criminal Limb

Inclusion under Article $6 \S 1$ of the ECHR

Civil Matters: YES

1) Consequences for property rights:

- expropriation (Prince Hans-Adam II of Liechtenstein v. Germany (2001));

- orders to demolish unlawfully erected buildings (Egger v. Austria (2003));

- approval of a contract when buying land by public authorities (Sramek v. Austria (1984));

- loss of capacity to administer property (Winterwerp v. the Netherlands (1979));

- consolidation of agricultural land (Ettl and others v. Austria (1987));

- permits: building permit (Mats Jacobsson v. Sweden (1990)); permit to retain estate (Håkansson and Sturesson v. Sweden (1990)), exemption permit from protected wetland (Alge v. Austria (2004));

- announcement of protected natural site (Oerlemans v. Netherlands (1991); designation of an area of outstanding beauty and of public interest (De Geouffre de la Pradelle v. France (1992));

- environment protection with influence on property right (e.g. right to a healthy living environment) - applicants' ability to use the water in their well for drinking purposes (Zander v. Sweden (1993));

- restoration of property rights (Jasiūnienè v. Lithuania (2003)).

2) Consequences for the performing of a function/profession; granting licences:

a) Granting/withdrawal of permits/concession/licenses to:

- run a pharmacy (G.S. v. Austria (1999));

- run a clinic (König v. Germany (1978); Kraska v. Switzerland (1993));

- manage a private school (Ingrid Jordebo Foundation of Christian Schools and Ingrid Jordebo v. Sweden (1987));

- perform commercial activities (liquid petroleum gas delivery, Benthem v. Netherlands (1985));

- perform public transport (Pudas v. Sweden (1987));

- sell alcohol beverages (Tre Traktörer Aktiebolag v. Sweden (1989)).

b) Right to perform a function/profession:

- right to exercise the profession of medical practitioner (König v. Germany (1978)) and its continuation (Albert and Le Compte v. Belgium (1983));

- exercise fishing rights (Posti and Rahko v. Finland (2002));

- enrolment on the list of pupil advocates (De Moor v. Belgium (1994)) and resuming practice as an advocate (H. v. Belgium (1987));

3) Association registration (APEH Üldözötteinek Szövetsége and Others v. Hungary (2000));

4) Change of name/surname (Mustafa v. France (2003); Petersen v. Germany (2001));

5) Access to documents held by public authorities (Loiseau v. France (2003));

6) Enrolment in higher education (Emine Araç v. Turkey (2008) / permitting specialization in medicine (Kök v. Turkey (2006)); 
7) Social security rights and obligations (Feldbrugge v. Netherlands (1986) - determination of the right to health insurance allowances; Salesi v. Italy (1993) - entitlement to disability allowances; Francesco Lombardo v. Italy (1992) - obligation of the State to pay a pension to a public servant; Massa v. Italy (1993) - right to a pension; Schuler-Zgraggen v Switzerland (1993) - right to an invalidity pension; Dumanovski v. The Former Yugoslav Republic of Macedonia - unemployment compensation (2005)).

8) Right to subsidies (Sotiris and Nikos Koutras Attee v. Greece (2000));

9) Patent application proceedings (British American Tobacco Company Ltd v. the Netherlands (1995));

10) Family disputes (O. v. United Kingdom (1987) - child care; P., C. and S. v. United Kingdom (2002) - parents right to have access to children; Keegan v. Ireland (1994) - adoption; Eriksson v. Sweden (1989) - foster care) ${ }^{30}$

11) Restitution of monies paid in tax (National and Provincial Building Society, the Leeds Permanent Building Society and the Yorkshire Building Society v. United Kingdom (1997)); refund of a tax credit (DC v. Italy (1992)); tax foreclosure (K. v Sweden (1991)); ${ }^{31}$

12) Damages in administrative proceedings (X. v. France (1992));

13) Disciplinary proceedings influencing civil rights (Le Compte van Leuven and De Meyer v. Belgium (1981); Bayer v. Germany (2009); Olujić v. Croatia (2009)).

\section{Criminal Matters: YES}

1) Tax penalties (OAO Neftyanaya Kompaniya Yukos v. Russia (2009));

2) Tax surcharges (Jussila v. Finland (2006));

3) Customs offence (Salabiaku v. France (1988));

4) Disciplinary proceedings (Campbell and Fell v. the United Kingdom (1984));

5) Administrative penalties and misdemeanours (Öztürk v. Germany (1984); Malige v. France (1998); Garryfalou AEBE v. Greece (1997); Flisar v. Slovenia (2011));

6) Administrative criminal proceedings because of a labour inspection (Blum v. Austria (2005)).

Source: ECtHR Case Law; Sever (2014)

However, there are certain domains of public law where its characteristics "prevail" over private law and the ECtHR does not include them under the civil or criminal limb. As such, we can particularly expose tax law (except "sanctions" as mentioned above). Namely, defining a taxable person and tax assessment are sovereign and autonomous rights of each individual State. Moreover, the ECtHR excludes from the civil and criminal limb immigration law, public funds payments, political rights, etc. (see Table 3). It does not

\footnotetext{
${ }^{30}$ See Mole and Harby (2006).

${ }^{31}$ See Leszczyńska (2009).
} 
include the right to participate in the civil service and other branches of state authorities (police, judiciary, etc.). ${ }^{32}$ Public servant disputes do not fall within Article $6 \S 1$ of the ECHR when public servants perform state sovereign authority. ${ }^{33}$ Namely, as established in the Pellegrin case (1999), there is a special bond between a public servant and the State, requiring a special obligation of trust and loyalty. ${ }^{34}$ On the other hand, the ECtHR established applicability of Article $6 \S 1$ for pension disputes since upon retirement the special bond between the State and the public servant ceases to exist. ${ }^{35}$

Table 3: ECtHR Interpretation of Article $6 \$ 1$ of the ECHR in Terms of Public (Administrative) Law Matters - Exclusion

\section{Exclusion from Article $6 \S 1$ of the ECHR}

Civil Matters and Criminal Matters: NO

1) Taxes:

- tax assessment (X. v. France (1987));

- reimbursement of a turnover tax (X. v. Austria (1980)).

2) Aliens, citizenship (immigration law):

- entry, stay and deportation of aliens (Maaouia v. France (2000); Singh and Uppal v. United Kingdom (1979));

- permanent residence (Ilić v. Croatia (2000));

- right to a citizenship and issuance of a passport (Peltonen v. Finland (1995));

3) Public funds payments (Rotenstein v. the Federal Republic of Germany (1984)); ${ }^{36}$

4) Decision to revoke a university's status as a higher education institution (Slavic University in Bulgaria and others v. Bulgaria (2004));

5) Political rights:

- right to cooperate in parliament and local authorities (X. v. United Kingdom (1978); Priorello v. Italy (1985); Pierre-Bloch v. France (1997));

6) Access to place of employment/dismissal; promotion when working for the State or State administration - if the public servant does not have access to the court in accordance with the national legislation and the exclusion is justified on objective grounds in the State's interest (Vilho Eskelinen and others v. Finland (2007));

7) Procedure to challenge the investigating judge (Schreiber and Boetsch v. France (2003));

\footnotetext{
${ }^{32}$ Grotrian (1996).

${ }^{33}$ Pellegrin v. France (1999). In this case, the ECtHR set up a "functional criterion based on the nature of the employee's duties and responsibilities".

${ }^{34}$ The activities particularly exposed by the ECtHR were armed forces activities and police (see Pellegrin v. France (1999, par. 66)).

${ }_{35}$ Pellegrin (1999, par. 67).

${ }^{36}$ Grotrian (1996).
} 
8) Disciplinary proceedings by the Bar Association and Medical Chamber (X. v. Belgium (1980); ${ }^{37}$ by army or in prisons (if the prescribed penalty is not severe (Štitić v. Croatia (2007)); ${ }^{38}$

9) Non-severe interim measures (e.g. interim withdrawal of a driving licence), etc.

Source: ECtHR Case Law; Sever (2014)

However, in Vilho Eskelinen and others v. Finland (2007), the ECtHR re-examined the functional criterion developed in the Pellegrin case and concluded that certain public servant disputes were also to be counted as regular disputes between an employer and an employee, falling under the civil limb. These disputes can only be excluded if the State proves that the public servant has no access to the court and that such exclusion is justified on objective grounds in accordance with the State's interest. Exercise of power conferred by public law is not in itself decisive. ${ }^{39}$ Finally, exclusion from Article $6 \S 1$ guarantees as regards ordinary labour disputes, such as disputes about salaries, allowances, etc., on the basis of the special nature of relationship between the particular public servant and the State, is not justified. ${ }^{40}$

\section{Conducting Procedures within a Reasonable Time}

In accordance with the principle of checks and balances and the rule of law, administrative actions are subject to judicial review. Aiming at the effectiveness of the administrative system as a whole, it is important that all levels of decision-making, administrative and judicial, are performed effectively and in accordance with the principle of legality. When a public (administrative) law matter falls within the civil or criminal limb as defined by Article $6 \S 1$ of the ECHR, the State needs to ensure access to the tribunal and fair procedure(s) within a reasonable time. However, not every decision-making authority in the process needs to have judiciary powers. Namely, when the first (and second) instance is performed by the administrative body, the issued decision needs to be subject to a judicial review by a tribunal fulfilling the conditions set by Article $6 \S 1$ of the ECHR. ${ }^{41}$

More instances usually mean longer procedures. Therefore, when estimating the time that elapsed between the beginning of the procedure and the actual possibility of the party to exercise a right or fulfil an obligation, the ECtHR also takes into account preliminary procedures (e.g. interim measures) ${ }^{42}$ and the execution procedure following the judgment on the merits. In addition, disputes before the constitutional court are taken into account

\footnotetext{
37 Vitkauskas and Dikov (2012).

${ }^{38}$ Gorjanc-Prelević (2009).

${ }^{39}$ Vilho Eskelinen and others v. Finland (2007, par. 62).

${ }^{40}$ Vilho Eskelinen and others v. Finland (2007, par. 62). E.g. Article 6 is applicable for wrongful dismissal at embassy (Cudak v. Lithuania (2010, par. 44-45)).

${ }^{41}$ See Albert and Le Compte (1983). Cf. Sever (2016).

${ }^{42}$ See Guide on Article 6, right to a fair trial, civil limb (2013).
} 
when determining the above period, if the constitutional court's decision could affect the outcome of the case litigated before ordinary courts. ${ }^{43}$ Furthermore, when estimating the overall duration, the ECtHR will also take into account the returning of the cases to lower instances. ${ }^{44}$ Finally, Article $6 \S 1$ of the ECHR does not oblige the States to establish courts of appeals. However, if appeal is provided by national legislation, Article $6 \S 1$ of the ECHR guarantees are valid also for these proceedings. ${ }^{45}$

As regards ECHR validity in the contracting States, the ECtHR can consider violations only from the day of ratification on (the ratione temporis rule), despite the fact that procedures might have started before the ECHR entered into force in the respective State. Nevertheless, when estimating the reasonableness of procedure duration, the ECtHR will also examine the stage and state of procedure on the day of ratification, meaning that it will also indirectly take into account the period before ratification. ${ }^{46}$ Even though the State is obliged to comply with the ECHR from the ratification onwards, it will also be held responsible for violations that started beforehand, but are still going on after the ratification. ${ }^{47}$

As deriving from the ECtHR case law, when establishing the relevant time and its (un)reasonable length in administrative matters, the period to be taken into consideration starts when the dispute arises. That is, either with the starting of the administrative procedure $^{48}$ or when submitting an appeal to a second instance administrative authority, if that is a prerequisite to have access to the court and file a lawsuit against an administrative act. ${ }^{49}$ On the other hand, in criminal matters the decisive criterion as regards the beginning of such period is the official communication of criminal charges to the individual (presumption of committing a criminal offence). ${ }^{50}$

However, it should be noted that the ECtHR has not established "reasonable time" in abstracto. The reasonableness of the procedure duration needs to be estimated in each individual case separately, based on the standards set by the relevant ECtHR case law. The criteria used by the ECtHR are as follows: complexity of the case, conduct of the applicant and conduct of the authorities, what was at stake for the applicant in the dispute, and the circumstances of each individual case: ${ }^{51}$

a) Complexity of the case, relating to factual (complexity of evidence-taking procedure, contesting important facts, number of parties and applications, proposal of interim orders, etc.) or legal issues (procedural and substantive; e.g. solving questions where no case law has yet been established or the latter is not uniform).

\footnotetext{
${ }^{43}$ Poiss v. Austria (1987, par. 52); see Antolič v. Slovenia (2006, par. 17).

44 Vajagić v. Croatia (2006, par. 44-45, 50).

${ }^{45}$ See Delcourt v. Belgium (1970, par. 25).

${ }^{46}$ Galič (2000).

${ }^{47}$ Kurić and others v. Slovenia (2010, par. 240). Cf. Sever (2016).

${ }^{48}$ Schmidtova v. Czech Republic (2003, par. 55-58) in Gorjanc-Prelević (2009).

${ }^{49}$ See Janssen v. Germany (2001, par. 40); König v. Germany (1978, par. 98).

${ }^{50}$ Deweer v. Belgium (1980).

${ }^{51}$ Buchholz v. Germany (1981, par. 49); Frydlender v. France (2000, par. 43). See also Galič (2004); Sever (2016).
} 
b) Conduct of the applicant - the applicant should try not to delay the procedure on purpose and should use the possibilities provided by national law to shorten the procedures. However, submitting a complaint or other legal remedy does not count as delaying a procedure. ${ }^{52}$ The applicant must act with diligence, enable good functioning of proceedings and refrain from actions depending on him and prolonging the procedure (e.g. unnecessary supplement of an application, requests to extend time limits, replacing the representative, etc.). The ECtHR examines whether the applicant's conduct contributed to delay significantly, also taking into account the actions taken to prevent an unfavourable decision for the applicant, clearly showing no interest in speedy procedures (e.g. requesting a stay of proceedings). ${ }^{53}$

c) Conduct of the authorities - according to the ECtHR, in terms of Article $6 \S 1$ of the ECHR only delays attributable to the State can be taken into account. ${ }^{54}$ The State is obliged to organise its legal system in accordance with the requirements deriving from Article $6 \S 1$ of the ECHR. Objections such as overloaded courts due to reorganisation, delays by court experts, counterparty avoidance, or troubles in taking evidence, were not accepted as justified excuses by the ECtHR. Furthermore, national courts are obliged to provide an expeditious trial, despite the fact that in civil matters the initiative to start proceedings is on the party. ${ }^{55}$ Moreover, the State is also responsible when an authority, being one of the parties, causes delay. ${ }^{56}$ The possibility to extend time limits for public authorities does not exclude the State's responsibility for delays. ${ }^{57}$ However, the ECtHR did take into consideration certain temporary and exceptional societal or political circumstances in the transitional period (e.g. time of transition from a communist regime to a democratic market-economy system). ${ }^{58}$ Similarly, the States are not liable for temporary backlogs due to exceptional circumstances ${ }^{59}$ if they take appropriate and prompt measures to deal with such exceptional situation (e.g. interim measures, such as prioritising cases by urgency and relevance, as well as by what is at stake for the involved individuals or business entities). However, when such provisional measures become constant practice to deal with an overload, this points to structural deficiencies of the system and the State should introduce effective measures $^{60}$ to improve the legal and, consequently, the business environment. Moreover, the ECtHR also deemed as an acceptable stay of procedure the time necessary to wait for a decision from another authority or a decision on precedent. ${ }^{61}$ Finally, the State is not only responsible for judicial authorities, but for all public institutions. ${ }^{62}$

\footnotetext{
52 Lesar v. Slovenia (2006, par. 30).

53 See Peterke and Lembcke v. Germany (2009).

${ }^{54}$ Ciricosta and Viola v. Italy (1995, par. 28).

55 Guincho v. Portugal (1984, par. 32); Scopelliti v. Italy (1993, par. 25).

${ }^{56}$ H. v. the United Kingdom (1987, par. 84); cf. X. v. France (1992, par. 42).

57 Baraona v. Portugal (1987, par. 56).

58 Cf. Maltzan and others v. Germany (2005).

${ }^{59}$ E.g. temporary excess of work.

${ }^{60}$ Zimmerman and Steiner v. Switzerland (1983, par. 29). Cf. Mennitto v. Italy (2000, par. 30).

${ }^{61}$ Klasen v. Germany (2006, par. 35).

${ }^{62}$ Martins Moreira v. Portugal (1988, par. 60); Guide on Article 6, right to a fair trial, civil limb (2013).
} 
d) What was at stake for the applicant - the significance of the case for the applicant is important, since also a favourable yet late decision can in reality mean justice denied (e.g. when deciding about the rights of HIV-positive patients ${ }^{63}$ ). In particular, the ECtHR established that special diligence is needed in labour disputes, ${ }^{64}$ pension disputes, ${ }^{65}$ disputes about custody and relations with children, ${ }^{66}$ proceedings on civil status and capacity. ${ }^{67}$ Namely, some of these procedures can be crucial not just for the individuals, but also for business entities.

Finally, the ECtHR estimates the duration of procedures at all instances and establishes their overall duration. Thus, it does not focus only on overdue time. ${ }^{68}$ Nevertheless, even when a certain stage of procedure takes longer time, the ECtHR will not find violations if the overall duration of procedure was still within reasonable time. ${ }^{69}$ Accordingly, the ECtHR establishes violation of Article $6 \S 1$ of the ECHR due to unreasonably long procedures, ranging from over 2 years $^{70}$ to over 9 years (see Table 4 ), always depending on the circumstances of each individual case and according to the criteria analysed above.

Table 4: Case Law on Issuing Decisions in (Un)reasonable Time in Administrative Matters in Accordance with Articles 6 and 13 of the ECHR in Selected EU Member States

\begin{tabular}{|l|l|l|l|l|}
\hline \multicolumn{1}{|c|}{ Matter } & \multicolumn{1}{|c|}{ Right } & \multicolumn{1}{c|}{$\begin{array}{c}\text { Duration - } \\
\text { Relevant Period }\end{array}$} & Violation & \multicolumn{1}{c|}{ Just Satisfaction } \\
\hline $\begin{array}{l}\text { Deumeland (1986) } \\
\text { Germany }\end{array}$ & $\begin{array}{l}\text { widow's } \\
\text { supplementary } \\
\text { pension }\end{array}$ & $\begin{array}{l}10 \text { years, 7 months, } \\
\text { weeks }\end{array}$ & $6 / 1$ & $\begin{array}{l}\text { issuance of a judgment } \\
\text { as such is just } \\
\text { satisfaction }\end{array}$ \\
\hline $\begin{array}{l}\text { Salesi (1993) } \\
\text { Italy }\end{array}$ & $\begin{array}{l}\text { disability } \\
\text { allowance }\end{array}$ & slightly over 6 years & $6 / 1$ & $\begin{array}{l}\text { altogether damage: } \\
11,000,000 \text { Italian lire }\end{array}$ \\
\hline $\begin{array}{l}\text { Fuchs (2003) } \\
\text { Poland }\end{array}$ & $\begin{array}{l}\text { building } \\
\text { permit, } \\
\text { demolition } \\
\text { order }\end{array}$ & 9 years, 8 months & $6 / 1$ & $\begin{array}{l}\text { non-pecuniary damage: } \\
\text { EUR 8,000 }\end{array}$ \\
\hline $\begin{array}{l}\text { Božić (2006) } \\
\text { Croatia }\end{array}$ & pension right \\
\hline $\begin{array}{l}\text { Šilc (2006) } \\
\text { Slovenia }\end{array}$ & $\begin{array}{l}\text { register in the } \\
\text { Registry of } \\
\text { Attorneys }\end{array}$ & 7 years, 11 months & $6 / 1$ and 13 & $\begin{array}{l}\text { non-pecuniary damage: } \\
\text { EUR 2,000 }\end{array}$ \\
\hline $\begin{array}{l}\text { Grässer (2006) } \\
\text { Germany }\end{array}$ & right to build & 28 years, 11 months & $6 / 1$ & $\begin{array}{l}\text { non-pecuniary damage: } \\
\text { EUR 45,000 }\end{array}$ \\
\hline
\end{tabular}

${ }^{63}$ See X. v. France (1992).

${ }^{64}$ Habič v. Slovenia (2013, par. 40).

${ }^{65}$ H.T. v. Germany (2001, par. 37).

${ }^{66} \mathrm{H}$. v. the United Kingdom (1987, par. 85).

${ }^{67}$ Bock v. Germany (1989, par. 38, 48-49).

${ }^{68}$ Cf. Urbančič (2012); Sever (2016).

${ }^{69}$ Guide on Article 6, right to a fair trial, civil limb (2013): Pretto and others v. Italy (1983, par. 37).

${ }^{70}$ See X. v. France (1992, par. 31).

Continued on next page 
DOI: 10.2478/danb-2018-0007

\begin{tabular}{|l|l|l|l|l|}
\hline \multicolumn{1}{|c|}{ Matter } & \multicolumn{1}{|c|}{ Right } & \multicolumn{1}{c|}{$\begin{array}{c}\text { Duration - } \\
\text { Relevant Period }\end{array}$} & Violation & \multicolumn{1}{c|}{ Just Satisfaction } \\
\hline $\begin{array}{l}\text { Vilho Eskelinen } \\
\text { and others (2007) } \\
\text { Finland }\end{array}$ & $\begin{array}{l}\text { employment } \\
\text { dispute by } \\
\text { public } \\
\text { servants - } \\
\text { wage } \\
\text { supplement }\end{array}$ & over 7 years & $6 / 1$ and 13 & $\begin{array}{l}\text { non-pecuniary damage: } \\
\text { EUR 2,500 per } \\
\text { applicant }\end{array}$ \\
\hline $\begin{array}{l}\text { Vassilios } \\
\text { Athanasiou and } \\
\text { others } \\
\text { Greece }\end{array}$ & $\begin{array}{l}\text { claim for } \\
\text { additional } \\
\text { retirement } \\
\text { premium by } \\
\text { Army } \\
\text { Solidarity } \\
\text { Fund }\end{array}$ & 13 years, 8 months & $6 / 1$ and 13 & $\begin{array}{l}\text { non-pecuniary damage: } \\
\text { EUR 14,000 per } \\
\text { applicant }\end{array}$ \\
\hline $\begin{array}{l}\text { Wurzer (2012) } \\
\text { Austria }\end{array}$ & $\begin{array}{l}\text { right to } \\
\text { participate in } \\
\text { building } \\
\text { permit } \\
\text { procedure }\end{array}$ & 6 years and a half & $6 / 1$ & $\begin{array}{l}\text { non-pecuniary damage: } \\
\text { EUR 1,500 }\end{array}$ \\
\hline
\end{tabular}

Source: ECtHR Case Law; Sever (2014)

When deciding on just satisfaction for established violations, the ECtHR can decide on either pecuniary or non-pecuniary damage as long as the applicant sought and quantified just satisfaction. ${ }^{72}$ Sometimes, just satisfaction is the issuance of the judgment itself. For example, when an heir enters and continues the procedure before the ECtHR ${ }^{73}$ (see Table 4). The ECtHR needs to establish a causal link between the violation of a right to a trial within a reasonable time and the alleged pecuniary damage, which is a rather rare situation. ${ }^{74}$ On the other hand, there is a strong but rebuttable presumption of the existence of non-pecuniary damage due to violation of reasonable time. ${ }^{75}$ When assessing compensation, the ECtHR grants the same amount in comparable and similar cases, ${ }^{76}$ based on the following criteria: same duration of procedure, same number of levels of jurisdiction, stakes of equivalent importance and similar conduct of the party, same country. ${ }^{77}$ Moreover, the ECtHR also takes into account the economic circumstances of the respective country. Therefore, granted compensations may vary among countries. Finally, the ECtHR decides about the size of awards for non-pecuniary damage depending on

\footnotetext{
${ }^{71}$ Note: Pilot Judgment - structural problem in legal system - many ECtHR judgments delivered on excessive length of judicial proceedings in Greece, with majority of excessively long administrative proceedings.

72 H. v. The United Kingdom (1987, par. 92); Deumeland v. Germany (1986, par. 98).

73 Deumeland v. Germany (1986, par. 97). Cf. Sever (2016).

${ }^{74}$ Guillemin v. France (Article 50) (1998, par. 25); see Štokalo and others v. Croatia (2008, par. 72). Cf. Sever (2016).

75 Urbančič (2012); Scordino v. Italy (no. 1) (2006, par. 204); Sever (2014).

76 ... "assessment on an equitable basis"... (Plotnikovy v. Russia (2005, par. 34)).

${ }^{77}$ Cocchiarella v. Italy (2006, par. 138). Cf. Sever (2016).
} 
the duration of procedure and the circumstances of the case, such as the applicant's age, health, personal income, nature of request ${ }^{78}$ and domestic court awards, the applicant's contribution to procedure duration, ${ }^{79}$ what was at stake for the applicant, ${ }^{80}$ length of the enforcement proceedings, ${ }^{81}$ and other relevant aspects. ${ }^{82}$ As analysed in Table 4, just satisfaction varies from EUR 1,500 to EUR 45,000, depending on the circumstances of each individual case. For example, in the case of Vilho Eskelinen et al. (2007), the ECtHR established that the applicants had suffered distress and frustration due to excessive length of proceedings and awarded them EUR 2,500 in compensation for non-pecuniary damage. Similarly, in the Grässer case, it established that the applicant suffered a particularly grave violation of the right to a hearing within a reasonable time and suffered distress due to protracted length of the proceedings, which lasted for almost all his working life. Moreover, following the levy of execution to enforce court costs payment, he went bankrupt and his economic existence was at stake. In the light of these violations, the court awarded him compensation for non-pecuniary damage in the amount of EUR 45,000 (see Table 4).

\section{Conclusion}

Overall, it can be concluded that the ECHR standards of a fair trial and respect of human rights also apply to administrative justice systems in the EU Member States. Moreover, the ECHR also has indirect impact on the Executive, requiring the conduct of administrative procedures within a reasonable time.

The ECtHR did not define civil matters in abstracto, but when the dilemma arises, it rather focuses on the actual content of each individual case and estimates whether certain conditions - as set up by case law - are fulfilled. When proceedings fall within the "public law sphere" at the national level, Article $6 \S 1$ of the ECHR may apply if their outcome is decisive for civil rights and obligations. Similarly, a substantive approach is used in criminal matters. Not having general and clear rules as to what falls under Article $6 \S 1$ of the ECHR causes a certain level of (legal) uncertainty for both parties and national authorities. Since the ECtHR follows a broad ECHR interpretation in accordance with real life society evolution (ECHR as a living instrument), a change in the future case law is possible as regards certain domains that are now excluded from Article $6 \S 1$ of the ECHR (such as tax law, ${ }^{83}$ immigration law, etc.). However, the ECHR rules are only minimal standards to be ensured in the contracting States and do not prevent them from introducing stricter and higher standards of human rights protection at the national level. These can contribute to preserving and fostering the rule of law and a business-friendly environment, appealing for new investments.

Therefore, knowledge of the ECtHR case law and its development is necessary for both individuals and business entities to effectively protect their rights, as well as for the

\footnotetext{
${ }^{78}$ Urbančič (2012): Grässer v. Germany (2006, par. 52, 66).

${ }^{79}$ Peryt v. Poland (2003). See Sever (2014).

${ }^{80}$ Urbančič (2012): Mennitto v. Italy (2000, par. 34).

${ }^{81}$ Burdov v. Russia (no. 2) (2009, par. 154).

${ }^{82}$ Plotnikovy v. Russia (2005, par. 34). Cf. Sever (2016).

${ }^{83}$ Except, e.g. tax penalties, which are now already included under the criminal limb, see Chapter II, Table 2.
} 
contracting States to improve their legal orders on time and avoid possible convictions before the ECtHR. It is not enough that legal remedies exist only ex forma, they need to be efficient and the State is obliged to ensure them. Moreover, the efficiency and adequacy of legal remedies need to be in place, proved by case law in practice and not just assumed. Finally, administrative decisions need to be subject to judicial review; however, administrative authorities are obliged to perform due process and issue lawful decisions, thus reducing courts caseload. Court action should be the last remedy taken by the parties in the case of the "worst" violations and should be concluded within a reasonable time.

\section{References}

Council of Europe. (2006). Report on the Effectiveness of National Remedies in Respect of Excessive Length of Proceedings. Retrieved January 11, 2017, from http://www.venice.coe. int/webforms/documents/default.aspx?pdffile=CDL-AD(2006)036rev-e.

Council of Europe/European Court of Human Rights. (2013). Guide on Article 6, Right to a Fair Trial, Civil Limb. Retrieved January 7, 2017, from http://www.echr.coe.int/Documents/Guide_Art_6_ENG.pdf.

Galič, A. (2000). Evropska konvencija človekovih pravic in Evropsko sodišče za človekove pravice [European Convention on Human Rights and European Court of Human Rights]. In Pavčnik, M.; Mavčič, A. (eds.). Ustavno sodstvo [Constitutional Justice]. Ljubljana: Cankarjeva založba.

Galič, A. (2004). Ustavno civilno procesno pravo, Ustavna procesna jamstva, Ustavna pritožba-meje preizkusa in postopek [Constitutional Civil Procedural Law, Constitutional Procedural Guarantees, Constitutional Complaint - Scope of Review and Procedure]. Ljubljana: GV.

Gorjanc-Prelević, T. (ed.) (2009). Pravo na suðenje u razumnom roku, Zbirka izabranih presuda Evropskog suda za ljudska prava u slučajevima protiv Bosne i Hercegovine, Hrvatske, Makedonije, Slovenije in Srbije [Right to a Trial Within Reasonable Time, List of ECtHR Judgements in matters v. Bosnia and Herzegovina, Croatia, Macedonia, Slovenia and Serbia]. Retrieved January 5, 2017, from http://www.hrc.unsa.ba/zbirkapresuda/PDFS/ zbirkapresuda.pdf.

Grotrian, A. (1996). Article 6 of the European convention on human rights: the right to a fair trial. Strasbourg: Council of Europe.

HUDOC, European Court of Human Rights. Retrieved January 5, 2017, from http://hudoc. echr.coe.int/.

Leszczyńska, A. (2009). The European Convention on Human Rights as an Instrument of Taxpayer Protection. In Włodzimierz, N.; Małgorzata, S. (eds.). Protection of Taxpayer's Rights: European, International and Domestic Tax Law Perspective. Warszawa: Wolters Kluwer business.

Macdonald, R. St. J., Matscher, F., and Petzold, H. (eds). (1993). The European System for the Protection of Human Rights. Dordrecht; Boston; London: M. Nijhoff Publishers. Miller, V. (2011). The European Convention on Human Rights and the Court of Human Rights: issues and reforms, House of Commons. Retrieved January 11, 2017, from file://C:/Users/Uporabnik/Downloads/SN05936\%20(1).pdf. 
Mole, N., and Harby, C. (2006). The right to a fair trial, A guide to the implementation of Article 6 of the European Convention on Human Rights, Human Rights handbooks, No. 3. Directorate General of Human Rights, Council of Europe. Retrieved January 11, 2017, from http://www.echr.coe.int/LibraryDocs/DG2/HRHAND/DG2-EN-HRHAND-03(2006).pdf.

Regulation of European Parliament and of the Council on an open, efficient and independent European administration (draft) (2016). Retrieved January 13, 2017, from file:///C:/Users/Uporabnik/Downloads/s-2014_2019-plmrep-COMMITTEES-JURI-DV 2016-04-20-1090614_CLEAN_EN\%20(2).pdf.

Sever, T. (2014). Pravno varstvo odločanja v razumnih rokih $v$ upravnih zadevah, doktorska disertacija [The Legal Protection of Issuing Decisions in a Reasonable Time in Administrative Matters]. PhD thesis, Ljubljana: Evropska pravna fakulteta.

Sever, T. (2016). Conducting procedures in administrative matters in reasonable time analysis of selected case law by the European Court of Human Rights versus Slovenia. International journal of public policy, 12 (3/4/5/6), 149-16.

Sever, T., Đanić, A., and Kovač, P. (2014). Judicial protection of timely decision-making in administrative matters in the light of European convention on human rights in Slovenia and Croatia, NISPAcee Conference, Budapest, May 2014, Government vs. governance in Central and Eastern Europe: from pre-Weberianism to neo-Weberianism?

Sever, T., Đanić, A., and Kovač, P. (2016). Effective legal protection against the excessive length of administrative decision-making: the cases of Slovenia and Croatia. The NISPAcee journal of public administration and policy, 9 (1), 135-166.

Sever, T., Rakar, I., and Kovač, P. (2014). Protecting Human Rights Through Fundamental Principles of Administrative Procedures in Eastern Europe. DANUBE, Law and Economics review, 5 (4), 249-275.

Urbančič, M. (2012). Nepremoženjska škoda zaradi kršitve pravice do sojenja brez nepotrebnega odlašanja [Non-pecuniary Damage due to Violation of a Right to a Trial without Undue Delay]. Pravna praksa, 31(5), II-VIII.

Van Dijk et al. (eds.) (2006). Theory and Practice of the European Convention on Human Rights (4th ed.). Antwerpen, Oxford: Intersentia.

Vitkauskas, D., and Dikov, G. (2012). Protecting the right to a fair trial under the European Convention on Human Rights. Strasbourg: Council of Europe, Human Rights Handbooks. White, R. C. A., and Ovey, C. (2010). Jacobs, White, and Ovey: the European Convention on Human Rights (5th ed.). New York: Oxford University Press.

Zupančič, B. M. (2004). O razlagi sodnih precedensov in sodb ter posebej sodb Evropskega sodišča za človekove pravice [About the Interpretation of Judicial Precedents and Judgments and Especially European Court of Human Rights Judgments]. Revus, 2(2), 9-27. 